\title{
Od emblematów do plakatów. Kontinuum czy nowa forma?
}

\begin{abstract}
Abstrakt: The 17th and 18th century emblems strongly marked their presence in everyday life. They drew attention, intrigued, made people reflect. They were an inseparable companion of man. They dignified important events, both private and public ones. Today these are the functions of posters. Therefore, it seems justified to deliberate whether the two fields of art are somehow linked or whether each of them is something totally different.
\end{abstract}

Key words: Emblem, poster, word, picture, France

Emblematyka jest gatunkiem powstałym na styku sztuk plastycznych i literatury. Intensywnie rozwijała się w drugiej połowie XVI w., osiągając szczyt rozwoju w wieku XVII. Jest to gatunek sztuki, do którego należą zarówno słowa jak i obrazy. Ich świadome połączenie w określone związki ma służyć poznaniu i rozumieniu świata, wyjaśniać jego tajniki i ukazywać mechanizmy działania rzeczywistości, którą człowiek tworzy i która go otacza. Za inicjatora, prawodawcę i twórcę, który określił kształt $^{1}$ owego cieszącego się wielkim uznaniem gatunku uważany jest

1 Alciatus określił trójczłonową budowę emblematu. Zatem klasyczny emblemat winien składać się z inskrypcji zwanej również mottem, obrazu i subskrypcji będącej zwykle wierszem lub fragmentem większej literackiej 
Andreas Alciatus², którego potomność obdarzyła mianem „Emblematum Pater et Princeps", czyli Ojciec i Władca Emblematów. W 1531 r. w Augsburgu wydana została jego pierwsza praca emblematyczna pt. Emblematum liber, w związku z powyższym data ta uznawana jest za datę powstania owej formy symbolicznego przekazu³.

Alciatusowa koncepcja emblematu, jako utworu łączącego słowo i obraz dojrzewała powoli i przebiegała drogą swoistych meandrów, zwłaszcza w fazie początkowej ${ }^{4}$. Niemożliwym jest, aby coś powstało z niczego, więc i emblematyka nie powstała z próżni. Jej twórcy sięgali do korzeni starochrześcijańskich i średniowiecznych. Opierali się również o wzorce starożytne, gdyż już w starożytnym Egipcie używano przekazu słowno-obrazowego. Twórcy nowożytnej emblematyki uważali, że egipskie pismo hieroglificzne było pierwszą formą przekazywania myśli za pomocą symbolu, a co za tym idzie stało się protoplastą emblematu. W kręgu kultury helleńskiej, hellenistycznej i latyńskiej rzeźbiono bóstwa i osoby, które ubogacano sentencjami i wierszami mającymi na celu wyjaśnianie sensu rzeźb. Te maksymy w słowie miały wyrazić to, co określały wizualnie kształty i barwy odpowiadających im dzieł. Sentencje i wiersze znajdowały się nie tylko na rzeźbach, ale także umieszczane były na płaskorzeźbach w wewnętrznym i zewnętrznym wystroju rzymskiej architektury. Zapoczątkowaną tradycję z pogańskiego Rzymu przejął Rzym chrześcijański. W okresie prze-

całości. Por. M. Lurker, Przesłanie symboli w mitach, kulturach i religiach, Kraków 1994, s. 99-100.

2 Andreas Alciatus (1492-1550) - włoski prawnik, logik i poeta. Jego młodzieńcze historyczne i filologiczne zainteresowania oraz pasja poznawania dawnej kultury, z resztą typowa dla ludzi renesansu, a także zafascynowanie światem dawnych pomników i towarzyszących im inskrypcji, czyli pewnych powiązań słowa i obrazu, przyczyniły się do powstania dzieła, które dało początek emblematyce jako gatunkowi łączącemu słowo i obraz.

3 J. Pelc, Emblematy, ksiażki emblematyczne. Problemy teorii a praktyka twórców, „Barok. Historia - Literatura - Sztuka”, R. III, nr 1 (5): 1996, s. 33; J. Pelc, Barok - epoka przeciwieństw, Kraków 2004, s. 77.

4 J. Pelc, Emblematy, książki emblematyczne..., s. 34. 
śladowań i działalności w katakumbach chrześcijaństwo wytworzyło własną symbolikę, która nawiązywała do Starego i Nowego Testamentu. Łączyła tradycje hebrajskie i egipskie, z greckimi i rzymskimi ${ }^{5}$.

Za źródło emblematu w średniowieczu uznaje się heraldykę, gdzie znakowi godła rycerskiego towarzyszyła zwykle krótka sentencja. Ta konstrukcja składająca się z dwóch członów była zwana dewizą. U wczesnych humanistów termin dewiza oznaczał połączenie jakiegoś symbolu, wizerunku $\mathrm{z}$ mottem ${ }^{6}$. Takie połączenie ukazuje już wyraźnie konstrukcję preemblematyczną ${ }^{7}$.

Pierwsze wydanie Emblematów stanowiło ważne wydarzenie dla elity europejskich humanistów ${ }^{8}$. Jednak sam Alciatus odniósł się do niego krytycznie, gdyż twierdził, że zbyt mało uwagi jest w nim poświęcone związkom scripturae et picturae 9 . Dopiero edycja paryska wydana w 1534 r. została przez niego zaakceptowana, gdyż starała się dobitniej podkreślić jedność i zarazem autonomiczność kształtującej się coraz wyraźniej trójczłonowej kompozycji emblematów. Za przykład można podać emblemat Concordiae symbolum, który

5 J. Pelc, Stowo i obraz na pograniczu literatury i sztuk plastycznych, Kraków 2002, s. 15; L. Rotter, Emblematy jako wyraz postaw etyczno-moralnych. Zarys problematyki, [w:] Cnoty i wady. Społeczeństwo baroku po obu stronach Karpat, pod red. J. Marecki, L. Rotter, Kraków 2007, s. 81-82; Taż, Duchowość $i$ historia benedyktynek w symbolice malarskiej kościoła w Staniątkach, Kraków 2004, s. 99-103; P. Buchwald-Pelcowa, Emblematy w drukach polskich i Polski dotyczących XVI-XVIII wieku. Bibliografia, Wrocław 1981, s. 9; W. Tatarkiewicz, Historia estetyki, t. 3: Estetyka nowożytna, Warszawa 1991, s. 212.

6 J. Pelc, Stowo i obraz..., s. 16-17.

7 Z biegiem czasu terminu dewiza zaczęto używać zamiennie z terminami: sentencja lub lemma. Dwuczłonową dewizę określano także jako impresa, które z czasem Włosi stosowali jako nazwę emblematu. Por. J. Pelc, Słowo i obraz..., s. 17; W. Tatarkiewicz, Historia estetyki..., s. 211-212.

8 Jako przykład można podać Jana Dantyszka, poetę i dyplomatę Zygmunta I Starego, przy dworze Karola v, który jeszcze tego samego roku opublikował tekst noszący w nagłówku słowo Emblema. Był to dwuwiersz interpretujący symbol Feniksa opisujący postać zmarłego kardynała. Zob. J. Pelc, Emblematy, książki emblematyczne..., s. 36.

9 Por. Tenże, Słowo i obraz..., s. 25. 
w edycji z $1531 \mathrm{r}$. opatrzony był ryciną przedstawiającą kruka w koronie, a za nim gromadka innych kruków. W wydaniach kolejnych pojawia się nowy obraz, który bardziej eksponuje nie osobę władcy, a sam symbol władzy. Rycina przedstawia pionowo umieszczone berło na postumencie, wokół którego gromadzą się kruki. Może się wydawać, że nie jest to wielka różnica, jednak dla ludzi xvi w. była ona bardzo znacząca, bowiem podkreślała symboliczny charakter przesłania ${ }^{10}$.

Pierwsze wydanie Emblematum liber składało się ze 104 emblematów opatrzonych 98 rycinami. Następne edycje, z 1534 r. i jej wznowienie z 1542 r. zawierają kolejno po 113 i 115 emblematów i wszystkie były opatrzone odpowiednimi rycinami. Kolejne wznowienia z Wenecji (1546) i Lyonu (1547) nie zawierały przedstawień plastycznych do wszystkich emblematów. Ich liczba wahała się od 83 do 196 i z każdą kolejną edycją wzrastała. Do 1550 r. osiągnęła liczbę 211 emblematów z 209 rycinami zgrupowanymi w cykle tematyczne. Dzieło Andreasa Alciatusa znalazło szybko wielu naśladowców i kontynuatorów. Andreas Alciatus koncentrował się w swych utworach na problematyce etycznej, w nowy sposób prezentował nauki jak żyć cnotliwie oraz o jakich prawdach należy pamiętać, by ten cel osiągnąć. Znaki symboliczne, którymi się posługiwał komponując swe emblematy, były zakorzenione w kulturze europejskiej, w literaturze antycznej i biblijnej oraz w ikonografii starożytnej i chrześcijańskiej. Alciatus tworząc sięgał do poezji, bajek zwierzęcych, przysłów, anegdot, średniowiecznych bestiariuszy, a także do wyobrażeń spotykanych na starożytnych monetach i medalach. Ikoniczno-symboliczne części utworu musiały wyrażać sensy rozpoznawalne przez ludzi wykształconych. Na przykład oliwka jako atrybut bogini mądrości oznacza człowieka mądrego, a zwierzęta znane z bajek są synonimami cech ludzkich. Z kolei inne znaki symboliczne wymagały wiedzy historycznej, więc i sporej erudycji. Autor budował ze znanych symboli przedstawienia alegoryczne, które interpretował epigramat. Propozycja

10 Tenże, Emblematy, książki emblematyczne... s. 38. 
uniwersalnego kodu, który pozwalał opisywać ludzkie życie w sposób alegoryczny, a zarazem rozpoznawalny i obowiązujący przyjęła się i rozprzestrzeniła w zaskakująco szybkim tempie ${ }^{11}$.

Dla kształtowania się praktyki i teorii emblematów obok Alciatusa istotny wkład wnieśli inni twórcy emblematyczni, szczególnie z terenu Francji ${ }^{12}$, co nie jest bez znaczenia dla dalszej części niniejszej pracy. $\mathrm{W}$ niecałe 200 lat ukazało się ponad 3 tysiące książek $\mathrm{z}$ emblematami autorstwa prawie 700 pisarzy. W dawnych wiekach niewiele gatunków literackich osiągnęło tak ogromny zasięg ${ }^{13}$.

Wielkie zainteresowanie emblematyką sprawiło, że zbiory emblematów w pewnym sensie zaczęto specjalizować. Często poświęcano je konkretnym pojęciom, zjawiskom, wartościom. W xvıI w. za jedną z najważniejszych odmian emblematów uważa się utwory religijne i medytacyjne. Świadczy o tym dzieło belgijskiego jezuity Hermana Hugona Pia desideria. Było ono wznawiane prawie 50 razy, a łącznie

11 Tenże, Stowo i obraz..., s. 17-30; L. Rotter, Emblematy... s. 82-83; R. Krzywy, Rozwój sztuki emblematycznej, http://www.wilanow-palac.pl/rozwoj_sztuki_emblematycznej.html, [30 viII 2015].

12 W 1539 r., w Paryżu ukazało się dzieło Gauillaume de La Perrière (14991565) pt. Le Théâtre des bons engins, auqel contentus cent Emblemes..., w którym znajdowało się 100 wierszy, a każdemu z nich towarzyszył drzeworyt oraz tytuł [Dzieło francuskiego artysty ukazało się już 3 lata wcześniej, w 1536 roku, pod tym samym tytułem, ale bez rycin, ponieważ jak pisze badaczka francuskiej emblematyki Alison Saunders, Le Perrière był moralistą i nie wierzył w pełni wymowie obrazu]. W 1540 r., również w Paryżu kolejny twórca Gilles Corrozet (1510-1568) wydał zbiór Hecatomgraphie..., składający się ze 100 drzeworytów i odpowiadających im tekstów. Następnie Corrozet, twórca francuskiej wersji Bajek Ezopowych, które wydawane były z ilustracjami. W 1552 r. ukazało się dzieło, zawierające 106 emblematów, opracowanych przez kolejnego Francuza Barthélemy'ego Aneau pt. Picta poesis. Ut pictura poesis erit. Tytuł dzieła nawiązuje do znanej formuły z poetyki Horacego, która była często przywoływana przez twórców renesansowych. Por. J. Pelc, Słowo i obraz..., rozdz. I i II; Tenże, Barok..., s. 178; L. Rotter, Emblematy..., s. 83.

13 R. Krzywy, Rozwój sztuki emblematycznej, http://www.wilanow-palac. pl/rozwoj_sztuki_emblematycznej.html, [30 viII 2015]. 
powstało około 90 przekładów tego zbioru ${ }^{14}$. Stworzone przez niego emblematy prezentują drogę duszy do Boga. Droga ta składa się z trzech etapów: pokuty, świętych pragnień oraz zjednoczenia z Bogiem. Istotnym wątkiem w Pia desideria jest również centralny dla literatury i sztuki baroku konflikt między miłością boską i ziemską, które przedstawione są pod postaciami Amora i Kupidyna. Herman Hugo proponuje rozwiązać ten problem zgodnie z wytycznymi świętego Ignacego Loyoli, który polecał wykorzystywać słabość ludzką do dążenia ku Bogu ${ }^{15}$. Emblematy belgijskiego jezuity mają charakter medytacji religijnej, co czyni jego zbiór atrakcyjnym dla czytelnika epoki baroku ${ }^{16}$.

Emblematy istniały nie tylko w literaturze i w książkach, ale mogły być i były elementem dekoracji budynków, różnych przedmiotów, ogrodów, dekoracji związanych z okolicznościowymi festynami i spektaklami teatralnymi.

W okresie baroku zainteresowaniem cieszył się teatr i różne gatunki dramatyczne. Kompozycje emblematyczne wielokrotnie służyły jako podstawa schematu ich budowy. Emblematyka przenikała do dramatów i dialogów scenicznych poprzez frazeologię i metaforykę poetycką odpowiedniego typu. Sentencje i symbole emblematyczne pochodzące z różnych zbiorów emblematów wplatane były do tekstów dramatycznych. Bohaterowie poprzez nie bardzo często argumentowali swe wywody. W tragediach renesansowych i barokowych stosowano wszelkiego typu sentencje, gdyż były one uważane za słupy podtrzymujące konstrukcje dramatu ${ }^{17}$. Emblematy odcisnęły także swoje piętno na komediach i dramatach sielankowych.

14 Wśród nich znajdują się 3 tłumaczenia na język polski, z których za najważniejszy należy uznać przekład Aleksandra Teodora Lackiego zatytułowany Pobożne pragnienia.

15 H. Hugo, Pia Pia desideria emblematis elegiis at affectibus ss. Patrum illunstrata, Antwerpia 1624.

16 B. Czarski, Medytacje nad emblematami, http://www.wilanow-palac.pl/ medytacje_nad_emblematami.html, [30 viII 2015].

17 Z. Szmydtowa, Poeci i poetyka, Warszawa 1964, s. 94. 
Albrecht Schöne ${ }^{18}$ w swoim dziele ukazał jak ważną rolę odgrywały emblematy w dramacie i teatrze dworskim, liturgicznym, popularnym, szkolnym, jarmarcznym i operowym, a także w widowiskach liturgicznych, uroczystych procesjach, odpustach, w ingresach, tryumfach wodzów, dostojników świeckich i kościelnych oraz w uroczystościach rodzinnych takich, jak narodziny, śluby, czy pogrzeby ${ }^{19}$. Schöne ukazuje analogię strukturalną emblematu do powiązania $\mathrm{w}$ dramacie barokowym aktów i następujących po nich chórów. Akt był obrazem, natomiast chór subskrypcją komentującą obraz. W związku z tymi analogiami chóry barokowe przestały powoływać się na tradycje antyczne, a zaczęły korzystać z moralistycznych subskrypcji emblematycznych. Takie dramaty możemy spotkać w szkolnym teatrze jezuickim, teatrze szkół barokowych, czy teatrze dworskim, w którym szczególną rolę pełniły wstawki pantomimiczne i baletowe, $\mathrm{z}$ udziałem muzyki, będące obrazem bez słów ${ }^{20}$. Za przykład emblematycznego dramatu można podać Pastor Fido albo Konterfekt wierny Miłości, z włoskiego języka na polski świeżo przetłumaczony przez jednego Senatora Wielkiego ${ }^{21}$. Dzieło to składało się z pięciu aktów i zostało wydane w Toruniu w 1694 r., a następnie w $1722 \mathrm{r}$. Na początku każdego aktu zostały zamieszczone ryciny, które w wyraźny sposób nawiązywały do symboliki emblematycznej, odpowiedniej do treści aktów. Każdej rycinie towarzyszyła dwuwersowa inskrypcja, która zapowiadała ideę przewodnią przedstawioną $\mathrm{w}$ danym akcie. Po aktach na scenie pojawiał się Chorus, mający za zadanie skomentowanie i ocenienie akcji. Konstrukcja tego dzieła ewidentnie podkreślała emblematyczność struktury ${ }^{22}$.

18 Zob. A. Schöne, Emblematik und Drama im Zeitalter des Barock, wyd. 2, München 1968.

19 J. Pelc, Słowo i obraz..., s. 45-46.

20 A. Schöne, Emblemik und Drama..., s. 167-174; J. Pelc, Słowo i obraz..., S. 291-292.

21 J. Pelc, Słowo i obraz..., s. 292.

22 Tamże, s. 292. 
Dekoracja na scenie, a także postacie występujące w spektaklu, posługujące się symbolicznymi rekwizytami bardzo często charakteryzacje czerpały z ikonologii i emblematyki. Obramowanie sceny zwykle było wykonane w formie portalu lub bramy tryumfalnej, która zdobiona była obrazem i napisem. Pojawiały się również na scenie plansze z rycinami i inskrypcjami emblematycznymi, komentarzem oraz subskrypcją. W zależności od rodzaju spektaklu pojawiały się różne rekwizyty. Gdy np. dane przedstawienie teatralne związane było z pochodem tryumfalnym, to insygnia i napisy niesione w nim umieszczano potem na scenie, a aktorzy, którzy niejednokrotnie grali role alegoryczne, personifikujące pojęcia, cnoty, czy wady, w pochodzie byli statycznymi figurami, a w spektaklu wypowiadali swe kwestie. Tendencje do alegoryzacji, które już wcześniej istniały w sztuce ułatwiały szerokie przeniknięcie wzorców emblematycznych, a napływ emblematyki wzmacniał rolę elementów symbolicznych i alegorycznych w teatrze barokowym ${ }^{23}$.

Emblematyka odcisnęła swoje piętno także w barokowym kaznodziejstwie. Bez jej szczególnego uwzględnienia nie jesteśmy w stanie zrozumieć istoty głoszonych kazań, których moralistyka oparta była na odwołaniu do emblematycznych przykładów, a poza tym cała budowa kazania odnosiła się i czerpała wzór z trójczłonowej budowy emblematu ${ }^{24}$. Kaznodziejstwo szczególnie mocno rozwinęło się w pierwszej połowie xviI w. Czasy wojen i niepokojów, częstych konfliktów religijnych rodziły zapotrzebowanie na uprawianie płomiennego kaznodziejstwa, by poruszyć sumienia grzeszników. Barokowi kaznodzieje uważali za obowiązek odwoływanie się do popularnych emblematów, przywołując je jako przykłady w swym nauczaniu,

23 Tamże, s. 293.

24 Już święty Augustyn i święty Tomasz z Akwinu w swych dziełach głosili, że dobre kazanie powinno zawierać i wyrażać myśl przewodnią, odwoływać się do wyobrażeń plastycznych - imagines agentes, a następnie od mott powinna wychodzić dalsza część kazania, która by objaśniała myśl przewodnią i przywoływane obrazy. Por. J. Pelc, Słowo i obraz..., s. 46. 
wiedzieli bowiem, że ich odbiorcy swoją myśl wyrażają w sposób emblematyczny, dlatego tym językiem starano się do nich przemawiać ${ }^{25}$. Poruszając się $\mathrm{w}$ obszarze religijnym nie można nie wspomnieć o wpływie symboliki emblematycznej na wystrój kościołów. Szczególnie ważnym miejscem w kościele była ambona, z której głoszono Słowo Boże, stąd troszczono się o wystrój emblematyczno-symboliczny kazalnic, a program ich zdobnictwa zawsze był bardzo przemyślany i zaplanowany w najdrobniejszych szczegółach. Zdarzało się nawet, że kazalnice same w sobie były emblematami. Za przykład można podać kazalnicę zachowaną w warszawskim kościele Wizytek, która łączy późny barok i rokoko. Przedstawiona jest jako dziób okrętu, nad którym znajduje się zarys masztu. Pojawia się tam emblemat Ojczyzny i świętego Kościoła, który nawiązuje do Ewangelii świętego Łukasza, o czym informuje nas inskrypcja umieszczona na żaglu: „Jezus uczył z łódki” ${ }^{26}$. Tematyka religijna w emblematach przejawiała się także poprzez sławienie świętych i błogosławionych ${ }^{27}$, przy zachowaniu szczególnego kultu dla Maryi ${ }^{28}$. Generalnie sławiono w warstwie słownej, ponieważ w rycinach eksponowano zazwyczaj ujęcia ikonologiczne lub plastyczne, posiadające raczej ogólny charakter $^{29}$. W drugiej połowie XVII w. i początku wieku XVIII powszechne stało się czczenie w sposób uroczysty świąt kościelnych i ważnych wydarzeń z nimi związanych, typem przenośnych obrazów, czy relikwii. Były to okazje dobre ku temu by organizować procesje i aby je uświetnić wnoszono ołtarze, bramy i inne obiekty architektury okazjonalnej, na których umieszczone były emblematy. Zdarzało się

25 Tamże, s. 46, 204-209.

26 Tamże, s. 303-304.

27 Zob. L. Rotter, Duchowość i historia benedyktynek..., passim.

28 Za przykład można podać dzieło karmelity Sebastiana a Matre Dei, Firmamentum symbolicum, z 1652 r., w którym znajduje się pięćdziesiąt emblematów, sławiących i odnoszących się do cnót Maryi Panny. Por. J. Pelc, Barok..., s. 187 .

29 Tamże, s. 187. 
także, że wystawiano okolicznościowe sztuki, w których występowały dekoracje emblematyczne i postacie alegoryczne ${ }^{30}$.

Emblematy stosowane były również w tematyce poruszającej zagadnienia związane ze wzorem człowieka cnotliwego. Pojawiały się cykle ukazujące ludzi prawych, bogatych w cnoty, a także obrazy, które szczególną uwagę zwracały na sposób życia konkretnej grupy społecznej, bądź wydzielonej profesji. Jako przykład takiego dzieła można podać pracę Maksymiliana Fredry Peristromata Regum sive Memoriale Principis monitorum symbolis expresum, gdzie ukazany został obraz władcy, jako człowieka mądrego, wyrozumiałego i pełnego dobra. Innym dziełem ukazującym cnoty człowieka prawego było Adverbia moralia Stanisława Herakliusza Lubomirskiego. Zastosowanie takich emblematów znajdujemy również na polichromiach świątyń ${ }^{31}$.

Emblematy towarzyszyły także weselnym uroczystościom, w postaci symbolicznych dekoracji. Za przykład można podać ślub hetmana polnego litewskiego Stanisława Ernesta Denhoffa z Zofią z Sieniawskich, który miał miejsce we Lwowie w 1724 roku, gdzie na dziedzińcu zamkowym, obok dwóch okazjonalnych bram tryumfalnych: trzydzieści kolumn, różnymi do tego aktu tudzież do herbów zobligowanych domów alludujacemi, wymalowanych symbolami i inskrypcyjami od galerii zamkowej aż do bramy stało, które powkopywane w ziemię sosny z pięknym przeplatały prospektem ${ }^{32}$. W osobnej broszurce opublikowano łaciński tekst emblematów.

Emblematy, by uświetnić wesele nie muszą pojawiać się tylko w drukach i malowanych dekoracjach. Dawne podręczniki retoryczne nakazywały podkreślać uczoność okolicznościowych oracji poprzez

30 J. Pelc, Słowo i obraz..., s. 205-306.

31 L. Rotter, Duchowość i historia..., s. 121-122; J. T. Maciuszko, Symbole $w$ religijności polskiej doby baroku i kontrreformacji, Warszawa 1986, s. 176-188, J. Pelc, Barok..., s. 191.

32 R. Grześkowiak, Palmy nad Wisłą. Emblematy w staropolskim obrzędzie weselnym, http://www.wilanow-palac.pl/palmy_nad_wisla_emblematy_w_staropolskim_obrzedzie_weselnym.html, [1 1 I 2014$]$. 
wplatanie stosownych cytatów, sentencji, czy anegdot. Do roli erudycyjnego materiału idealnie pasowały symbole pochodzenia emblematycznego, zredukowane do zwięzłego opisu przedstawienia i inskrypcji. Rolę subskrypcji i komentarzy spełniała mowa, która interpretowała symboliczną kompozycję w zależności od potrzeb panegirycznej przemowy. $Z$ racji tego, że w starodawnej Polsce zwyczaje zalotów, zmówin, zaręczyn, ślubu, wesela były bardzo rozbudowane, ciągle rosło zapotrzebowanie na materiał erudycyjny. Jako inny przykład można podać ślub Zygmunta III Wazy z Anną Austriaczką. Specjalnie na tą okazję, w 1592 r. wybito srebrne żetony przedstawiające dwie palny rosnące na dwóch brzegach strumienia, stykające się wierzchołkami. Na obrazie widniała inskrypcja „Amor distantia iungit” (miłość łączy na odległość, to co odległe). Obraz miał symbolizować uczucie na przekór przeciwnościom. Podczas wjazdu Anny do Krakowa numizmat został rzucony w tłum. Dzięki temu wizerunek ten stał się jednym z najczęściej przywoływanych symboli Zygmunta III, który był powtarzany zarówno w literackich zbiorach emblematów, jak i na okolicznościowych medalach epitalamijnych ${ }^{33}$.

Ważną pozycję w emblematyce zajmowała tematyka dworska, której celem było uświetnianie życia dworskiego, sławienie czynów monarchów, wielmożów świeckich i duchowych, a także codziennych wydarzeń z życia dworzan ${ }^{34}$.

Wiek XVII naznaczył się w emblematyce europejskiej inwazją tematyki i symboliki erotycznej. Zaczęły powstawać całe cykle emblematów, które w różnoraki sposób przedstawiały Kupidyna ze strzałami, łukiem i pochodnią, którą rozniecał w sercach ludzkich miłość. Rozwój tematyki erotycznej nie oznaczał jednak apoteozy na jej cześć, ale towarzyszyła mu lekka nuta krytycyzmu, a także nuta umoralniająca ${ }^{35}$.

33 Tamże.

34 J. Pelc, Barok..., s. 190.

35 Tamże, s. 184-186. 
Emblematyka gościła także w drukach z okazji promocji akademickich. Były to utwory pochwalne nowo promowanych magistrów lub doktorów. Najczęściej pisał je jeden z laureatów. Na początku wymieniano zwykle liczbę laureatów oraz podawano informację pod czyimi auspicjami i pod czyim dozorem promocja doszła do skutku. Na odwrocie karty tytułowej umieszczano herb osoby, której zadedykowany był panegiryk. Najczęściej był to biskup krakowski. Następnie umieszczano właściwą dedykację, a po niej wiersz na cześć Jana Kantego, patrona instytucji oraz wiersze na cześć profesorów i egzaminatorów. Później zdarzało się, że po raz kolejny powtarzano tytuł lub bezpośrednio po wierszach umieszczano stemmata na cześć laureatów. Pod nazwiskiem laureata umieszczano jego herb lub jakiś symbol z nim związany, umieszczając wokół opis lub objaśnienie. Kolejno dawano lemmat, najczęściej wzięty z dzieł poetyckich. Dopiero pod tym drukowano wiersz związany z mottem oraz symboliką ryciny ${ }^{36}$.

Emblematy pojawiały się także w publikacjach poświęconych dysputom, drukach okolicznościowych: uroczystości rodzinne, narodziny, pogrzeby, czy w publikacjach poświęconych elicie intelektualnej, uświetniając koligacje ludzi wykształconych z patrycjatem miejskim ${ }^{37}$.

Wiek xvir był czasem wielkiego „autorytetu” emblematyki. Szukano w niej klucza do poznania i zrozumienia świata i dzieł Stworzyciela, a także tajników duszy i ciała człowieczego. W wieku xvıı można zauważyć powolny zmierzch znaczenia emblematyki. W niektórych krajach następował szybciej, w innych wolniej, ale kierunku przemian nic zawrócić nie mogło, zatem trwający blisko dwa stulecia jej rozkwit odszedł do historii ${ }^{38}$.

Jednak w chwili kiedy emblematy odchodziły w cień, Europę zalała fala afiszy, które stały się pierwowzorem plakatu. Plakat jest jedną $\mathrm{z}$ najmłodszych dziedzin grafiki. Wbrew pozorom nie jest to tylko

36 J. Pelc, Słowo i obraz..., s. 316-317.

37 Tamże, s. 309-329.

38 J. Pelc, Emblematy, książki emblematyczne..., s. 48-49. 
płachta jaskrawego papieru $\mathrm{z}$ wydrukowanym słowem, umieszczona na słupach ogłoszeniowych i witrynach sklepowych. Jest dziełem sztuki. Swą niezwykłością obrazu przyciąga oko odbiorcy, absorbuje, zwraca uwagę i sprawia, że przypadkowy przechodzień nieświadomie przyjmuje przeznaczoną dla niego informację $e^{39}$.

Spoglądając na plakat i mając na uwadze miejsce jego powstania można pokusić się o stwierdzenie, że jego prototyp stanowią omawiane powyżej emblematy, bowiem ich budowa i funkcja jest niemal identyczna jak budowa współczesnego plakatu. Poddając analizie zarówno jedno, jak i drugie podkreśla się analogiczne stosowanie figur myśli i figur słowa. Cechą wspólną omawianych gatunków jest pewna zagadkowość, obie te dziedziny sztuki intrygują, fascynują i nie pozostają obojętne na oko odbiorcy zmuszając go do wysiłku intelektualnego. Zmuszając do myślenia.

Ojczyzną plakatu bezspornie jest Francja i to właśnie tutaj należy upatrywać się jego narodzin jako gatunku artystycznego ${ }^{40}$. Zaś za ojca plakatu uznany został Jules Chéret ${ }^{41}$, który nadawał ton paryskiej ulicy. Po pobycie w Londynie, gdzie zapoznał się z arkanami wielobarwnej litografii wrócił do Paryża, by wprowadzić i zastosować nabytą wiedzę

39 Plakat polski, wstęp i opracowanie J. Waśniewski, Warszawa 1972, passim.

40 Sz. Bojko, Francja ojczyzna plakatu, „Przegląd artystyczny”, nr 2:1966, s. 3 .

41 Jules Chéret (1836-1932) - francuski grafik i malarz; jeden z pierwszych twórców nowoczesnego plakatu. Pracował w warsztacie litograficznym, gdzie od 1855 r. zaczął wykonywać swoje pierwsze plakaty (czarno-białe). Następnie wyjechał do Londynu (1859-1866), by tam poznać tajniki barwnej litografii. W 1881 r. założył w Paryżu własną pracownię litograficzną. Nawiązując do sztuki viII w. i malarstwa impresjonistycznego wypracował własny styl, który charakteryzował się lekkim, dynamicznym rysunkiem i żywym kolorytem. Wpływ na jego twórczość odcisnęła secesja, pod wpływem której zaczął stosować płaską i lapidarną formę o dużych wartościach dekoracyjnych. Tworzył ilustracje książkowe, obrazy olejne, a także dekoracje ścienne. Zbiór jego prac znajduje się w Musée Jules-Chéret w Nicei, gdzie żył i pracował w ostatnich latach życia. Zob. Chéret Jules [w:] Stownik sztuki francuskiej, pod red. A. Dulewicz, Warszawa 1977, s. 92-93. 
na rodzimej ziemi. Zaprojektował i osobiście wykonał na kamieniu przeszło 900 plakatów ${ }^{42}$. Jego dzieła charakteryzowały się wrażliwością malarską, pomysłowością i finezją. Zainicjował rodzaj ulicznego obrazu dla publiczności nieobytej ze sztuką, czym dał jej namiastkę doznań artystycznych, podobnie jak czyniła to ludowa twórczość anonimowa (muzykanci, cyrkowcy itp.). Pojawiające się na ulicach bardzo kolorowe, żartobliwe, czasem nawet frywolne plakaty były nowością powszechnie zwracającą uwagę przechodniów. Stały się jednym z elementów kształtujących wygląd ówczesnego Paryża, dodawały mu wdzięku i młodości. Przyjęły się, co sprawiło, że zamawiano ich coraz więcej i coraz to inne ${ }^{43}$.

Mimo, że to Chéret jako pierwszy zastosował kolorową litografię, to jednak kto inny uczynił z tej możliwości sztukę. Po etapie rzemieślników, rysowników i litografów plakatem zainteresowali się malarze ${ }^{44}$. Emil Zola w 1896 r. słusznie zauważył, że Salon gości teraz na ulicy, a nie na Champs-de-Mars. Artyści zaczęli zabiegać o to, by plakat otrzymał pełne prawa samodzielnego gatunku artystycznego. Pierwszym, który mu je nadał był Touluse-Lautrec ${ }^{45}$. Właściciele kabaretu „Moulin Rouge" w 1891 r. zaproponowali Lautrecowi, by przygotował reklamę na początek sezonu. Miała ona być bardziej pomysłowa od reklamy sporządzonej przez Chéreta $\mathrm{z}$ okazji inauguracji. Lautrec wykonał

42 Jako przykład można podać Bal au Moulin-Rouge z 1889 r., Pantomimes lumineuses z 1892 r., Folies Bergère - La Loïe Fuller z 1893, L' Eldorado z 1894, czy Palais de Glace z $1896 \mathrm{r}$.

43 Sz. Bojko, Polska sztuka plakatu. Początki i rozwój do 1939 roku, Warszawa 1971, s. 8-9.

44 Jako przykład można podać Pierre Bonarda, Eduarda Vuillarda, czy Jacquesa Villona.

45 Henri de Touluse-Lautrec (1864-1901) - malarz i grafik; przedstawiciel postimpresjonizmu. Swój styl odznaczający się silną ekspresją ukształtował pod wpływem grafiki japońskiej i malarstwa impresjonistów. Głównym źródłem tematów było dla niego życie wielkomiejskie. Jego plakaty wyróżniają się syntetyczną formą i mistrzowskim zestrojeniem elementów linearnych z płaską plamą koloru. Wywarły one wpływ na powstanie współczesnej sztuki plakatowej. Bogata kolekcja jego prac znajduje się w muzeum w Albi. Zob. Touluse-Lautrec Henri de [w:] Stownik sztuki francuskiej..., s. 408-409. 
kilka szkiców węglem i kredką. Stopniowo dokonywał eliminacji tego co zbędne i rozpraszające uwagę. Od japońskich artystów nauczył się sztuki zdecydowanych płaszczyzn barwnych, precyzyjnego rysunku i nasyconego koloru. Drzeworyty japońskie były sporządzane wytwornie i prosto, co odpowiadało jego wrodzonemu zmysłowi widzenia syntetycznego. Według niego przedmiot, czy figura powinna dać się ogarnąć jednym spojrzeniem, a każdy gest miał mieć jednoznaczną wymowę ${ }^{46}$. Tak powstał plakat z tańczącą kankana La Goulue, który rozwożony na wózkach reklamowych wywołał sensację społeczną. Plakaty Toulusa-Lautreca siłą zatrzymywały przechodnia i wręcz namawiały do odwiedzenia Eldorado, czy Moulin Rouge ${ }^{47}$.

Ostatnie dziesięciolecie xIx w. i pierwsza dekada xx w. zdominowana została przez secesję, określaną także jako Art Nouveau (Francja, Anglia), Jugendstil (Niemcy) lub Stile Liberty (Włochy). Secesja lubowała się w płynnych formach, bogatym ornamencie i gładkich liniach ${ }^{48}$. W Anglii w tym czasie tworzył Aubrey Vincent Beardsley ${ }^{49}$,

46 Lautrec doskonalił technikę litografii wprowadzając szereg pomysłów warsztatowych, np. dzięki zestawianiu obok siebie płaszczyzn czystego koloru otrzymywał prócz efektu dekoracyjnego, nowe, lapidarne działanie plamy, bądź pocierając palcem szczoteczkę do zębów rozsiewał drobne kropki na kamieniu litograficznym, które na odbitce tworzyły ziarnisty półton. Warto zauważyć, że Lautrec do każdego plakatu, który tworzył przygotowywał się tak, jak do malowania obrazów. Wpierw przygotowywał szereg szkiców kolorystycznych i kompozycyjnych, następnie szkic rysunkowy przenosił na płótno. Potrafił kłócić się z drukarzami o odcienie, które miały pojawić się na plakacie. Ponadto jego kieszenie zawsze wypełnione były szczoteczkami do zębów, dzięki którym uzyskiwał wyjątkowe efekty swoich dzieł. Sz. Bojko, Polska sztuka plakatu..., s. 10; J. Lenica, Plakat - sztuka dzisiejszych czasów, „Przegląd artystyczny”, nr 5:1952, s. 36.

47 Sz. Bojko, Polska sztuka plakatu..., s. 9-10; Sz. Bojko, Francja ojczyzna plakatu..., s. 3; J. Lenica, Plakat - sztuka dzisiejszych czasów..., s. 36.

48 Secesja [w:] Słownik terminologiczny sztuk pięknych, pod red. K. Kubalska-Sulkiewicz, M. Bielska-Łach, A. Manteuffel-Szarota, Warszawa 2007, s. 375-376.

49 Audrey Vincent Beardsley (1872-1898) - rysownik i ilustrator. Początkowo pracował jako urzędnik w towarzystwie ubezpieczeń, następnie za namową przyjaciół wstąpił do Westminster School of Art. Pierwsze poważne 
autor plakatów londyńskiego wydawnictwa Children’s Books. Jego dzieła charakteryzowały się dużymi plamami czerni lub kontrastowej barwy ozdobionymi plątaniną spirali delikatnych linii i ornamentów.

Wybitną postacią tego czasu był również Alfons Mucha ${ }^{50}$, czeski artysta, który prócz projektowania plakatów tworzył także okładki książek i czasopism oraz reklamy. Jego dzieła były typowe dla secesji: dekoracyjne, o stylizowanym rysunku i linii tworzącej płynny ornament.

Ważną postacią w historii plakatu był Théophil Steinlen ${ }^{51}$, który jako pierwszy wprowadził do plakatu wątek społeczny, a także uważany był za prekursora współczesnego plakatu politycznego, który datuje się od czasów Komuny Paryskiej. Artysta w swoich dziełach ukazywał Paryż plebejski, prosty, nie tętniący zbytkiem. Sporządzanie reklam towarów, lokali rozrywkowych, czy koncertów było dla niego pretekstem do artystycznego określenia stosunku do świata. Do jego

zamówienie dostał od wydawnictwa Dent na ilustracje do dwutomowej Śmierci Artura. Wykonał przeszło pięćset rysunków. Współpracował z Pall Mall Budget, a także był kierownikiem artystycznym Yellow Book (czasopismo reprezentujące angielski fin de siècle). Współpracował również z Savoy Magazine. Zob. M. Middleton, Beardsley Audrey Vincent [w:] Od Maneta do Pollocka. Stownik malarstwa nowoczesnego, Warszawa 1995, s. 26.

50 Alfons Mucha (1860-1939) - czeski malarz i projektant. Jest znany jako twórca plakatów o ornamentalnym i falistym rysunku, które zaliczane są do arcydzieł Art. Nouveau. Większość jego najlepszych plakatów powstała w Paryżu w latach 9o. Odniósł sukces w Stanach Zjednoczonych, dokąd czterokrotnie podróżował. W 1922 r. osiadł w Czechosłowacji, gdzie zajął się projektowanie m. in. znaczków i banknotów. Zob. Mucha Alfons [w:] Oksfordzka ilustrowana encyklopedia sztuki, pod red. J. J. Norwicha, Łódź 1994, s. 331.

51 Théopile Alexandre Steinlen (1859-1923) - szwajcarski rysownik, grafik i malarz. W 1883 wyjechał z Lozanny i osiadł w Paryżu. Publikował rysunki, tworzył plakaty, akwaforty, litografie i ilustracje książkowe. Był reprezentantem kierunku realistycznego ze szczególnym ukierunkowaniem na krytykę społeczną. Tematyką jego prac jest przede wszystkim życie proletariatu wielkomiejskiego. Zob. Steinlen Théophile Alexander [w:] Stownik sztuki francuskiej..., s. 399-400; Steinlen Théophile Alexander [w:] Słownik sztuki niemieckiej, pod red. A. Dulewicz, Warszawa 2002, s. 426-427. 
dzieł należy np. Affiches Charles Verneau, plakat reklamowy zaprojektowany w 1896 r. na zamówienie Zakładów Graficznych Charles Verneau. Plakat przedstawiał paryską ulicę, na której są zarówno praczki z tobołami bielizny, robotnicy, służące, jak i eleganckie mieszczki i ludzie interesu. W owym plakacie, poprzez charakteryzację postaci subtelnie różnicuje ich sytuację społeczną i materialną. Dzieła Steinlena stanowiły zapowiedź późniejszych plakatów o tendencjach politycznych i socjalnych ${ }^{52}$.

Fin de siècle ówczesnego plakatu następuje w xx w. Pojawia się technologia, przemysł i nowe techniki informacyjne. Sentymentalizm i wiążące się z nim wyobrażenia estetyczne wyparły nowe prądy umysłowe. Szczególnym zainteresowaniem cieszył się film niemy, który zwrócił uwagę na ekspresję przedmiotu utrwalonego w obiektywie, a także grafika reklamowa, która eksploatuje magiczną siłę obrazu przedmiotu. W 1908 r. na murach niemieckich miast naklejono plakat berlińskiego grafika Bernharda ${ }^{53}$, przedstawiający dwie zapałki. Była to reklama firmy zapałczanej Preister. Ten rok należy uznać za początek estetycznej kariery przedmiotu. Skończyła się epoka romantyczno-sentymentalna plakatu, odstąpiono od alegorii, wieńców, ornamentów i innych wdzięcznych scen rodzajowych, a przemówił obiekt ${ }^{54}$.

We Francji powoli przyswajano nową sztukę. Jak pisał Léger Francja ma wspaniałych artystów i intelektualistów, ale wlecze za sobą tradycje, która każe jej spoglądać do tyłu; posługując się przeszłością, okazuje lenistwo twórcze ${ }^{55}$. Plakat francuski mimo wszystko, u progu stulecia za-

52 Sz. Bojko, Polska sztuka plakatu..., s. 10-11; Sz. Bojko, Francja ojczyzną plakatu..., s. 3 .

53 Lucien Bernhard (1883-1972) - niemiecki grafik i ilustrator; jeden z pionierów nowoczesnej reklamy xx wieku. Stworzył formułę „plakatu przedmiotu”. W 1920 r. objął Katedrę Reklamy Berlińskiej Akademii Królewskiej. W 1923 r. wyemigrował do Stanów Zjednoczonych. Zob. S. Heller, Lucian Bernhard, http://www.aiga.org/medalist-lucianbernhard/ [25 V 2015].

54 Sz. Bojko, Francja ojczyznq plakatu..., s. 4.

55 F. Léger, Funkcje malarstwa, Warszawa 1970, s. 104. 
chował poetyckość, sprawiającą, że zwykłe, pospolite rzeczy ukazywały swój wdzię ${ }^{56}$.

Twórcą, który wyrażał postawę charakterystyczną dla okresu przejściowego był włoski artysta, Leonetto Capiello57. W 1903 r. zaprojektował plakat reklamujący szwajcarską czekoladę „Klaus”. Plakat przedstawiał czerwonego galopującego konia i jeźdźca-kobietę w rozwianej zielonej sukni. Wszystko to umieszczone było na czarnym tle. Artysta usunął $\mathrm{z}$ centrum uwagi reklamowany przedmiot, natomiast obraz pojęciowy identyfikujący się z nim utrwalał się. Elementy znajdujące się na plakacie zastępowały wyobrażenie przedmiotu. Były jego personifikacją, czy wizją poetycką ${ }^{58}$. Dzięki plakatom Capiellego mury miast przenosiły widza w świat bajki, nie zapominając jednak o współczesności i jej atrybutach ${ }^{59}$.

Po zakończeniu I wojny światowej mury państw europejskich zaczęły zdobić plakaty autorstwa francuskiego Cassandra, Charlesa Loupota, Paula Colina, angielskiego Mc Knighta Kauffera, szwajcarskiego Herberta Mattera, czy niemieckiego Herberta Bayera i Hansa Schlegera. Prace tych artystów zmuszały do zastanowienia się, nie były zwykłymi, prostymi i oczywistymi ulotkami informacyjnymi. Twórcy zaczęli wykorzystywać właściwości rozumu ludzkiego, pobudzili wyobraźnię i zaczęli posługiwać się skojarzeniami, symboliką przedmiotów i skrótów. Dzięki temu rozszerzono możliwości plakatu i wzbogacono jego język.

56 Sz. Bojko, Francja ojczyzna plakatu..., s. 4; A. A. Szablowska, Tadeusz Gronowski. Sztuka plakatu i reklamy, Warszawa 2005, s. 59.

57 Leonetto Capiello (1875-1942) - włoski grafik tworzący w Paryżu. Zajmował się rysunkami dla czasopism, ilustracjami książkowymi, a także projektował malowidła ścienne. Największą sławę przyniosły mu plakaty, bowiem wytworzył własny styl. W jego pracach widać zarówno dekoracyjność, jak i żywy kolor. Zob. Cappiello Leonetto [w:] Słownik sztuki francuskiej..., s. 75.

58 Artysta zaprojektował całą galerię symboli złączonych z dniem powszechnym, np. Turek w oparach filiżanki kawy Martin, Murzyn wyskakujący z łupiny orzecha dla margaryny Axa, czy chochlik opleciony skórką pomarańczy z Bitter Campari. Zob. Sz. Bojko, Francja ojczyzna plakatu..., s. 4.

59 Tamże, s. 4; A. A. Szablowska, Tadeusz Gronowski..., s. 59-60. 
Jednakże plakat, który jest sztuką masową musiał być zrozumiały dla tych, do których był skierowany, a przez swój rebusowy, ideowy charakter wielokrotnie był niejasny i trudny do odczytania. Owa niezrozumiałość sprawiła, że pozbawiono go wartości ideowych, przez co stał się marginesem sztuk plastycznych i lekceważoną grafiką użytkową. Dopiero Rewolucja październikowa przywróciła plakatowi pełnowartościowe prawa gatunku artystycznego. Początkiem 1918 r. na murach Piotrogrodu, Moskwy i innych miast rosyjskich zawisły plakaty polityczne mobilizujące robotników, żołnierzy i chłopów ${ }^{60}$. Tenże rodzaj plakatów nie kontynuował form istniejących w sztuce burżuazyjnej, lecz zapoczątkował nowy gatunek artystyczny zdominowany przez ideę i stał się nierozłącznym towarzyszem człowieka w pracy, w walce, ucząc i wychowując ${ }^{61}$.

Plakat kształtował się stopniowo i docierał do najbardziej odległych zakątków świata. Dzisiaj nie ma już takiego miejsca, do którego plakat by nie dotarł. Jest on nieodłącznym towarzyszem człowieka. Można go dostrzec w pracy, w szkole, na ulicy, w kinach, teatrach, domach kultury. Odbicie w plakacie znajduje każde ważne wydarzenie, czy to święto narodowe, czy akcja społeczna, gospodarcza, bądź polityczna. Różnorodność i ilość wydawanych plakatów stale wzrasta ${ }^{62}$. Z chwilą gdy narodziła się ta dziedzina sztuki rodzajów wydawanych plakatów było niewiele, zazwyczaj związane były z wydarzeniami ogólnonaro-

60 Plakat rosyjski przez wiele lat był nieodłączną częścią życia codziennego społeczeństwa rosyjskiego. Kształtował oblicza miast i wsi, sklepów, szkół, urzędów państwowych, garnizonów wojskowych, fabryk i zakładów pracy. Prezentował i sławił wodzów i bohaterów, ukazywał sukcesy i bogactwa kraju. Można było znaleźć na nim odpowiedź na każde pytanie, ukierunkowywał społecznie i moralnie, demonstrował ideały, kształtował ramy zachowania, a także wyznaczał granice dobra i zła. Por. A. Miodek, Fenomen plakatu rosyjskiego, http://aremio.blogspot.com/2014/o1/fenomen-plakatu-rosyjskiego. html [10 IV 2015].

61 J. Lenica, Plakat - sztuka dzisiejszych czasów..., s. 37.

62 Jako przykład można podać plakat polityczny. W początkowym okresie jego nakład był niewielki, natomiast dzisiaj wynosi od 50 tys. egzemplarzy, sięgając nawet do 200 tys. 
dowymi lub teatralnymi, z kolei dzisiaj każdy może odnaleźć plakat związany ze swoją branżą i środowiskiem ${ }^{63}$.

Plakat jest integralną częścią krajobrazu wsi i miast. Nie sposób przejść i nie zwrócić na niego uwagi. Jest na przystankach komunikacji miejskiej, billboardach, słupach ogłoszeniowych. Ze względu na rozległą tematykę, którą obejmuje można wyodrębnić cztery podstawowe grupy: plakat reklamowy, który powstał najwcześniej i zajmuje się propagowaniem wszelkiego typu towarów, plakat społeczno-polityczny, zwykle służący do celów propagandy politycznej, plakat artystyczny, którego celem jest informowanie o wydarzeniach artystycznych i kulturalnych oraz plakat turystyczny, do rozwoju którego przyczyniło się zainteresowanie społeczeństwa kulturą innych regionów i krajów ${ }^{64}$. W obrębie wyżej wymienionych grup można dokonać dalszych, szczegółowych podziałów ${ }^{65}$.

Do najbardziej popularnych należą plakaty reklamowe, które są formą grafiki użytkowej, mającej zaskakiwać i pozostawać w pamięci. Najczęściej rozwiesza się je na słupach ogłoszeniowych i na murach. Posiadają one ogromny potencjał i są dobrym sposobem na promowanie usług, produktów, czy firm. Plakat ma tą właściwość, że nie można go wyrzucić tak jak ulotki, ani przerwać jak reklamy radiowej, bądź telewizyjnej. Jednakowoż należy mieć świadomość, że człowiek spośród wielu mijanych plakatów zapamiętuje tylko kilka. Dlatego najistotniejszą cechą plakatu reklamowego jest zdolność zatrzymania przechodnia. Aby tego dokonać potrzeba inteligentnego pomysłu,

63 J. Bogusz, Niektóre problemy polskiego plakatu politycznego, „Przegląd artystyczny", nr 2:1953, s. 24.

64 Rodzaje plakatów można również podzielić na obrazowe, liternicze inaczej zwane typograficznymi i mieszane, składające się zarówno z części obrazowej, jaki i typograficznej. Ostatni z wymienionych rodzajów jest najczęściej występującym. Por. A. Miodek, Plakat jako forma wypowiedzi plastycznej, http://aremio.blogspot.com/2013/o6/plakat-jako-forma-wypowiedzi-plastycznej.html [12 v 2015].

65 L. Wojtasik, Psychologia propagandy politycznej, Warszawa 1986, s. 252253. 
co było, jest i zapewne będzie wyzwaniem dla artystów ${ }^{66}$. Pomysł ten musi łączyć estetykę z funkcjonalnością. Dobrze zaprojektowane plakaty reklamowe zawierają zredukowane słowa i elementy graficzne, bowiem widz ma ograniczony czas na ich odbiór. Siłę tego typu plakatów stanowią krótkie wyrazy i dominujący motyw widoczny z dużej odległości, a także kontrast. Wyraźne barwy skontrastowane ze sobą przyciągają wzrok odbiorcy i stanowią pomoc w zapamiętaniu przekazu. Kompozycja winna być kreatywna, zawierać element zaskoczenia, który wywoła u widza zainteresowanie, ciekawość oraz zachęci do ponownego zwrócenia uwagi na plakat, przy mijaniu go następnego dnia. Umieszczanie zbyt wielu informacji, stosowanie pastelowych kolorów oraz zbyt mała czcionka stanowią największy błąd przy tworzeniu plakatów reklamowych ${ }^{67}$.

Bardzo często na słupach ogłoszeniowych, tzw. okrąglakach można zobaczyć plakaty promujące wydarzenia kulturalne, np. plakat filmowy, który przekazuje komunikat odnośnie konkretnego wydarzenia. Odebranie go nie wymaga od społeczeństwa nadmiernego wysiłku, ani co bardziej istotne nakładu czasu. Idąc ulicą wystarczy tylko na niego spojrzeć. Wpierw dostrzega się obraz, a gdy spełni swoją rolę, zainteresuje widza, wtedy swój przekaz realizuje tekst ${ }^{68}$. Podobne do plakatów

66 Jednak dla zaspokojenia potrzeb fabrykantów produkujących artykuły masowego spożycia w latach 50, 60 i $70 \mathrm{xx}$ w. trzeba było tworzyć również plakaty mniej elitarne, przedstawiające np. ułana rozmawiającego $\mathrm{z}$ dziewczyną i trzymającego w dłoni kufel piwa określonej firmy. Plakaty te były uznawane przez artystów za zło konieczne, które jest spowodowane niskim poziomem kultury społeczeństwa nie rozumiejącego „prawdziwej sztuki”.

67 J. Bogusz, Niektóre problemy polskiego plakatu politycznego..., s. 26-27; M. Napierała, Filozofia reklamy, Kraków 2012, s. 39-40; M. Brzostowski, Techniki reklamy, Warszawa 1977, s. 50, 61; D. Bernstein, Billboard - reklama otwartej przestrzeni, Warszawa 2005, s. 94; J. Kall, Reklama, Warszawa 1995, s. 154; Dobry plakat reklamowy, http://moja-reklama.pl/dobry-plakat-reklamowy/ [12 V 2015]; Plakat reklamowy, http://www.stroer.pl/outdoor/plakat-reklamowy [12 V 2015].

68 P. Szarek, Stodka obietnica filmowej przygody. Co nam mówią plakaty filmowe?, http://www.ikonosfera.umk.pl/index.php?id=82 [23 IV 2015]. 
filmowych są plakaty teatralne, rodzaj kurtyny, za którą czeka spektakl. Stanowią korelację słowa i obrazu. Zawierają autora i tytuł spektaklu, nazwiska głównych bohaterów, a także miejsce i datę przedstawienia. Obraz zwykle współgra z tytułem, rzadziej jest to wybrana scena ze spektaklu ${ }^{69}$.

Plakat stanowi niezwykle istotną rolę w procesie porozumiewania się ludzi. Należy do tego rodzaju sztuki, który w sposób intensywny i wyraźny podkreśla swoją obecność w życiu codziennym, a także odzwierciedla przemiany zachodzące w świecie. Skupia uwagę, intryguje, czasem zmusza do refleksji, ponadto informuje, reklamuje i kształci ${ }^{\circ}$. W pewnej mierze kształtuje fizjonomię miast i stanowi wymowne świadectwo kultury danego środowiska ${ }^{71}$. Wszystkie te elementy sprawiają, że spełnia rolę nowożytnych emblematów. Ponadto tak samo jak obok miejsc, w których są zachowane dzieła emblematyczne nie sposób przejść nie zwracając na nie uwagi, tak samo nie sposób minąć plakat bez „rzucenia” nań okiem.

Projektując plakat trzeba mieć na uwadze to, że w ramach pewnej kompozycji plastycznej musi być zawarta także treść, czyli struktura semantyczna. Nie można dokonać analizy artystycznej plakatu pomijając kompozycję napisu. Wzajemne relacje słowa i obrazu decydują o efektywności przekazywanego komunikatu² ${ }^{72}$ Twórcy plakatów poświęcali tyle samo uwagi przy opracowaniu szczegółowo każdej litery i napisu, co przy projektowaniu obrazu, np. dla Cassandra napis był punktem

69 Theatre Posters, http://www.vam.ac.uk/content/articles/t/theatre-posters/ [23 IV 2015]; Afisz teatralny, http://www.aict.art.pl/sownik-teatralny/ id.afisz-teatralny/i.html [23 IV 2015].

70 J. Brukwicki, Sztuka ulicy. Współczesny plakat polski, http://www.galeriasztuki.wloclawek.pl/wydarzenia/299-sztuka-ulicy-wspolczesny-plakatpolski [20 VI 2015].

71 S. Machniewicz, Wybór pism estetycznych, Kraków 2012, s. 196.

72 M. Knorowski, Kolekcja plakatu polskiego Xx wieku, http://www.postermuseum.pl/wirtualne-muzeum/kolekcja-plakatu-polskiego/ [28 IV 2015]; O. Halldin, The history of posters, http://www.kb.se/docs/collections/history-posters.pdf [30 IV 2015]. 
wyjścia w tworzeniu plakatu. W 1926 r. powiedział: To właśnie tekst $i$ kształtujace go litery wprowadzaja w ruch cały mechanizm tworzenia $w$ moich plakatach. One prowokuja pewne związki idei, będące źródtem formy plastycznej. Element słowny rzutuje na element przestrzenny. Poza słowem, na kształt plakatu wplywa ściśle narzucony format. Z tego punktu widzenia sztuka plakacisty współczesnego posiada pewne analogie ze sztuka dawnego heraldyka, który musiał na ograniczonej przestrzeni zawrzeć określone atrybuty i sentencje. A więc tarcza herbowa, poprzez obiektywny schematyzm, mówiące symbole, żywe kolory, a wreszcie przez swoją dewizę, zdaje się być autentycznym początkiem plakatuㄱ. Zatem plakat składa się z obrazu i słowa, świadomego połączenia tych dwóch elementów, ich korelacji. Czyż kilka wieków wcześniej z tych samych elementów nie składał się emblemat? Myślę więc, że można pokusić się o stwierdzenie, iż plakaty stanowią kontinuum nowożytnych emblematów.

Przemawia za tym przede wszystkim konstrukcja obu dzieł, co wielokrotnie w niniejszej pracy zostało podkreślone. Ponadto oba gatunki powstały i rozwijały się na tym samym obszarze geograficznym, co również ma niebagatelne znaczenie. Barokowi artyści poprzez swoje dzieła umieszczane w miejscach publicznych i powszechnie odwiedzanych, w sposób symboliczny przekazywali pewne wartości i treści oraz ubogacali krajobraz kulturowy. Ich rolę przejęli i obecnie kontynuują plakaciści. Ich dzieła są nośnikiem informacji i nieodłącznym elementem krajobrazu. Analogiczna jest zatem powszechność i dostępność zarówno emblematów jak i plakatu. Obydwa mają z założenia oddziaływać na szeroko rozumiane społeczeństwa. Jednak z założenia także, obydwie formy poprzez zastosowanie przekazu symbolicznego i połączenie obrazu oraz słowa, ukierunkowują swój przekaz w stronę tej części społeczeństwa, która jest zdolna taki przekaz odczytać i zrozumieć zgodnie z wolą autora. Doświadczenie przekazu emblematów oraz plakatu wymaga zatem w równym stopniu od widza: szerokiej wiedzy, umiejętności kojarzenia faktów, rozumienia języka symboli.

73 A. A. Szablowska, Tadeusz Gronowski..., s. 115-118. 


\section{Bibliografia}

Afisz teatralny, http://www.aict.art.pl/sownik-teatralny/id.afisz-teatralny/i.html [23 IV 2015].

Bernstein D., Billboard - reklama otwartej przestrzeni, Warszawa 2005.

Bogusz J., Niektóre problemy polskiego plakatu politycznego, „Przegląd artystyczny", nr 2:1953, s. 24-40.

Bojko Sz., Francja ojczyzna plakatu, „Przegląd artystyczny”, nr 2:1966, s. 3-11.

Bojko Sz., Polska sztuka plakatu. Początki i rozwój do 1939 roku, Warszawa 1971.

Brukwicki J., Sztuka ulicy. Współczesny plakat polski, http://www.galeriasztuki.wloclawek.pl/wydarzenia/299-sztuka-ulicy-wspolczesnyplakat-polski [20 vi 2015].

Brzostowski M., Techniki reklamy, Warszawa 1977.

Buchwald-Pelcowa P., Emblematy $w$ drukach polskich i Polski dotyczacych XVI-XVIII wieku. Bibliografia, Wrocław 1981.

Czarski B., Medytacje nad emblematami, http://www.wilanow-palac. pl/medytacje_nad_emblematami.html, [30 VIII 2015].

Dobry plakat reklamowy, http://moja-reklama.pl/dobry-plakat-reklamowy/ [12 V 2015].

Grześkowiak R., Palmy nad Wisłą. Emblematy w staropolskim obrzędzie weselnym, http://www.wilanow-palac.pl/palmy_nad_wisla_emblematy_w_staropolskim_obrzedzie_weselnym.html, [1 I 2014].

Halldin O., The history of posters, http://www.kb.se/docs/collections/ history-posters.pdf [30 IV 2015].

Heller S., Lucian Bernhard, http://www.aiga.org/medalist-lucianbernhard/ [25 V 2015].

Hugo H., Pia Pia desideria emblematis elegiis at affectibus ss. Patrum illunstrata, Antwerpia 1624.

Kall J., Reklama, Warszawa 1995. 
Knorowski M., Kolekcja plakatu polskiego xx wieku, http://www.postermuseum.pl/wirtualne-muzeum/kolekcja-plakatu-polskiego/ [28 IV 2015].

Krzywy R., Rozwój sztuki emblematycznej, http://www.wilanow-palac. pl/rozwoj_sztuki_emblematycznej.html, [30 viII 2015].

Léger F., Funkcje malarstwa, Warszawa 1970.

Lenica J., Plakat - sztuka dzisiejszych czasów, „Przegląd artystyczny”, nr 5:1952, s. 35-52.

Lurker M., Przesłanie symboli w mitach, kulturach i religiach, Kraków 1994.

Machniewicz S., Wybór pism estetycznych, Kraków 2012.

Maciuszko J. T., Symbole w religijności polskiej doby baroku i kontrreformacji, Warszawa 1986.

Middleton M., Beardsley Audrey Vincent [w:] Od Maneta do Pollocka. Słownik malarstwa nowoczesnego, Warszawa 1995, s. 26.

Miodek A., Fenomen plakatu rosyjskiego, http://aremio.blogspot. com/2014/o1/fenomen-plakatu-rosyjskiego.html [10 IV 2015].

Miodek A., Plakat jako forma wypowiedzi plastycznej, http://aremio. blogspot.com/2013/o6/plakat-jako-forma-wypowiedzi-plastycznej. html [12 V 2015].

Napierała M., Filozofia reklamy, Kraków 2012.

Oksfordzka ilustrowana encyklopedia sztuki, pod red. J. J. Norwicha, Łódź 1994.

Pelc J., Barok - epoka przeciwieństw, Kraków 2004.

Pelc J., Emblematy, ksiażki emblematyczne. Problemy teorii a praktyka twórców, „Barok. Historia - Literatura - Sztuka”, R. III, nr 1 (5):1996, s. 33-58.

Pelc J., Słowo i obraz na pograniczu literatury i sztuk plastycznych, Kraków 2002.

Plakat polski, wstęp i opracowanie J. Waśniewski, Warszawa 1972, passim.

Plakat reklamowy, http://www.stroer.pl/outdoor/plakat-reklamowy [12 V 2015]. 
Rotter L., Duchowość i historia benedyktynek w symbolice malarskiej kościoła w Staniątkach, Kraków 2004.

Rotter L., Emblematy jako wyraz postaw etyczno-moralnych. Zarys problematyki, [w:] Cnoty i wady. Społeczeństwo baroku po obu stronach Karpat, pod red. J. Marecki, L. Rotter, Kraków 2007, s. 81-103.

Schöne A., Emblematik und Drama im Zeitalter des Barock, München 1968, wyd. 2.

Słownik sztuki francuskiej, pod red. A. Dulewicz, Warszawa 1977.

Słownik sztuki niemieckiej, pod red. A. Dulewicz, Warszawa 2002.

Stownik terminologiczny sztuk pięknych, pod red. K. Kubalska-Sulkiewicz, M. Bielska-Łach, A. Manteuffel-Szarota, Warszawa 2007.

Szablowska A. A., Tadeusz Gronowski. Sztuka plakatu i reklamy, Warszawa 2005.

Szarek P., Słodka obietnica filmowej przygody. Co nam mówią plakaty filmowe?, http://www.ikonosfera.umk.pl/index.php?id=82 [23 IV 2015].

Szmydtowa Z., Poeci i poetyka, Warszawa 1964.

Tatarkiewicz W., Historia estetyki, t. 3: Estetyka nowożytna, Warszawa 1991.

Theatre Posters, http://www.vam.ac.uk/content/articles/t/theatre-posters/ [23 IV 2015].

Wojtasik L., Psychologia propagandy politycznej, Warszawa 1986. 